\title{
A REVIEW: THE ENERGY POVERTY ISSUE IN THE EUROPEAN UNION AND LATVIA
}

\author{
D. Zalostiba, D. Kiselovs \\ Riga Technical University, Institute of Power Engineering, \\ 12-1 Azenes Str., Riga, LV-1048, LATVIA \\ e-mail: diana.zalostiba@rtu.Iv
}

Energy poverty is a growing concern in the European Union. Following energy market liberalization, the problem of energy affordability has entered the political discussion, making it necessary to estimate its dimensions, develop and implement a policy and means for its mitigation. To evaluate the situation in Latvia, the paper reviews the way energy poverty is currently defined and measured, investigating the advantages and shortcomings of various definitions and approaches. It then provides a brief analysis of energy poverty in three characterising dimensions: low income, high costs of energy services and unsatisfactory housing conditions (primarily related to energy efficiency aspects), using available statistical data. The characterising indicators of energy poverty are compared with the EU average values. Finally, this paper highlights individual policy measures for diminishing energy poverty.

Keywords: Energy access, energy communities, energy poverty, fuel poverty, renewables.

\section{INTRODUCTION}

The availability and utilization of energy have a direct impact on the wellbeing of society and enable a dignified standard of living as well as full-fledged participation in the life of society. The increase in the prices of energy resources and the impact of the 2007-2010 global financial crisis have affected many people, increasingly exacerbating the issue of energy poverty ${ }^{1}$ and protection of the most vulnerable social groups.

Energy poverty is often characterised as

\footnotetext{
${ }^{1}$ On the whole, the issues related to energy poverty are defined and described by using a number of terms, including the following: fuel poverty, energy insecurity, energy precariousness, energy affordability etc. Still, all of these refer to the inability to obtain energy or meet a certain level of energy needs. The present publication uses the terms "fuel poverty" and "energy poverty" interchangeably.
} 
a situation in which a household or an individual is unable to meet their local energy needs. As a result, there is an adverse impact on the quality-of-life indicators characterising the welfare of the household or the individual and on the energy sector as a whole, as well as such areas as the healthcare, consumption and housing sectors. Reduction of energy poverty is topical not only in developing countries but it has also become a social priority at the EU level.

When looking at the Energy Union Strategy [1], which is based on five mutually complemented and closely interconnected dimensions, namely, (1) energy security, solidarity and trust; (2) a fully integrated European energy market; (3) energy efficiency contributing to moderation of demand; (4) decarbonising the economy, and (5) research, innovation and competitiveness, it can be seen that much attention is devoted to issues related to the reduction of energy poverty and the protection of vulnerable energy users. EU Directive 2019/944 stipulates that "energy services are fundamental to safeguarding the well-being of the Union citizens. Adequate warmth, cooling and lighting, and energy to power appliances are essential services to guarantee a decent standard of living and citizens' health. Furthermore, access to those energy services enables Union citizens to fulfil their potential and enhances social inclusion. Energy poor households are unable to afford those energy services due to a combination of low income, high expenditure on energy and poor energy efficiency of their homes." The EU member states have been assigned with the task to estimate the scale of energy poverty, develop and implement policy tools for its reduction.

In the recent years, new smart technologies and methods have been developed and introduced to the market for improving energy efficiency and energy saving, changing the way of energy consumption, providing flexibility to the grid and economic benefits to the energy market players. The potential and impact of the employment of such technologies are also studied in Latvia, e.g., in [2]-[5]. As noted in [6], citizens engaging in the energy community support energy transition and boost social innovation, positively impacting the mitigation of energy poverty and lowering the barriers that stop vulnerable groups from participating in, and gaining benefits from, the energy market.

To evaluate the situation in Latvia, a study was made, which focused on the definition of energy poverty, assessment of energy poverty evaluation approaches and the characterising indicators, as well as the analysis of good practices and policies. The paper is arranged in four sections. The next section provides a background of theoretical studies on the definition of energy poverty, evaluation approaches and the related issues. The subsequent section provides an analysis of energy poverty and the policies and measures to reduce energy poverty are described. The concluding section discusses the importance of energy poverty assessment and energy poverty mitigation instruments, focusing attention on energy communities.

\section{THEORETICAL STUDY}

\subsection{Definition of Energy Poverty}

After the 1973 oil crisis and the sharp fluctuations of fuel prices, concerns increased regarding the impact of the availability of energy services, especially the 
availability of heat and its impact on public health. At that time, the statistical data regarding mortality showed the highest number of deaths in the winter months, which was supposedly due to poor housing in the United Kingdom, which increased the heating bills. During the late 1970s and the early 1980s, the understanding of fuel poverty was developed, defining the concept of fuel poverty [7], [8].

In 1991, Brenda Boardman in her publication provided the first quantitative fuel poverty definition, namely, "the inability to afford adequate warmth because of the inefficiency of the home", setting a limiting value of $10 \%$ of the household's income as allotted to energy. This led to the acceptance of a nationwide definition in the United Kingdom: "A household is in fuel poverty if, in order to maintain a satisfactory heating regime, it would be required to spend more than $10 \%$ of its income (including Housing Benefit or Income Support or Mortgage Interest) on all household fuel use" [7]-[9].

In 2013, the definition in England was transformed, using the Low Income, High Cost (LIHC) approach proposed in [10], [11] and a corresponding indicator: a household is considered energy poor if its required fuel costs are higher than the nationwide median value and if meeting these costs results in the household falling below the official poverty line.

As pointed out by [12], [9], the United Kingdom has had a considerable impact on the discussions about energy poverty, influencing both research and policies; this results in focusing on heat comfort, heating being regarded as the most important service while other energy services are discussed less frequently. Yet the lack of other energy services, for example, air conditioning, lighting, transport etc., may have as dramatic effects as those that arise due to lack of heating. It has to be pointed out that the situation has been changing lately and in the discussion of energy poverty, much attention is devoted to energy services overall.

Moore (2012) [13] draws attention to the need to develop the definition further, since it is closely linked to and influences formulation of policies, determination of the scale and nature of the problem, mapping out of the strategy and progress observation. In addition, it is suggested that the definitions of energy poverty be differentiated into ones that are needed for forming national or regional policies and ones that are needed for identifying energy poor households locally.

The research [14] points out that Thomson, upon investigating the use of the terms "fuel poverty" and "energy poverty", by analysing more than 187 official EU policy documents over the recent thirteen years, finds that preference has been given to the term "energy poverty" (in more than $70 \%$ of the cases). Still, these terms are also used interchangeably in the same contexts. The Directive on the Internal Market for Electricity, which assigns the member states with the task to define more vulnerable consumers, uses the term "energy poverty", and, according to [14], Thomson concludes that since there are no directions at the EU level, the member states are not sure as to how to act. Up to now, there has been a lack of suitable tools for evaluating the scale of the problem. Moreover, the definition of energy poverty often has a narrower meaning in legal acts (referring only to electricity and gas).

In another study [15], which investigates how energy poverty is understood in Europe and discusses various indicators of energy poverty, this concept is defined as the inability of a household (or difficulty experienced by it) to access the energy it needs to ensure a dignified standard of living at an 
acceptable price in terms of its income. To introduce such a definition, it is necessary to have a unanimous understanding as to what constitutes a dignified standard of living, adequate heating levels and costs at an acceptable price, and it is possible that this understanding will differ in different member states, although the consequences are the same (energy use ceases, energy bills are not paid, etc.).

Over the recent years, studies [16], [17] have been focusing on developing and implementing a globally applicable definition of energy poverty as "the inability to attain a socially and materially necessitated level of domestic energy services" (the meaning of "socially necessitated" is usually understood as such a standard of energy services that enables a person to fully participate in society whereas the material aspect has to do with effects on health, mental health and well-being). In parallel, the authors of [18] have initiated a detailed discussion regarding the need to consider and evaluate a wider range of [energy] services, looking at how and for what reasons vulnerable households may suffer from energy poverty, using energy for other purposes than heating, how household electronic appliances (for meeting primary needs) influence energy consumption, how that influences the quality of life in various dimensions, as well as revisiting the grouping of protected customers, for example, adding the groups of students or young adults.

The authors of [19] also support a unified EU definition. This study argues that such a definition has an important role and that its introduction would impact three directions: political acknowledgement (better political visibility), fine-tuning (elimination of terminological unclarity) and synergy of policies (links with other spheres), especially at a time when the energy prices are increasing, the wages remain unchanged and concerns are growing as regards energy security and climate change. Likewise, the European Economic and Social Committee (EESC) recommends in its opinion that the European Commission should use a unified term.

Contrary to the arguments in [19], [20] holds that a common EU definition of energy poverty would be problematic and that democratically elected national governments would benefit from choosing their own definitions of energy poverty and policies in this field since there are considerable differences in energy availability. The study [20] points out that before the definition and evaluation criteria of energy poverty are incorporated into policy formation and policy assessment processes, a thorough assessment is needed. As a result of political pressure, policymakers may support the introduction of such policies that ensure greater improvements in official indicators rather than greater improvements in wellbeing.

A number of studies show that different indicators and the corresponding concepts may be suitable for different tasks in the context of evaluating energy poverty, for example, [21] suggests dividing the policy-making regarding energy poverty into three independent steps: definition of policy goals (this pertains to the choice of the target group, the political feasibility of such a choice and its economic costs), determination of energy poor homes (this pertains to the choice of the household identification process, the choice of identification criteria and the actual identification of the poor households) and implementation of policies (for example, choosing the most appropriate policy measures; direct interaction with the household; an evaluation of the acceptance level regarding the measures, etc.).

It has to be pointed out that in devel- 
oped countries, energy poverty usually has to do with a lack of energy affordability; it is constituted by a number of issues that preclude consumers from achieving the level of energy services or the level of thermal comfort needed to ensure a normal way of life, which is often regarded as the basic necessary level [7], [9], [22], [23]. On the other hand, in developing countries, energy poverty is usually related to the unavailability of energy and lack of access; the phenomenon has been subjected to a more multi-disciplinary approach, concentrating on the issues of energy availability or unavailability, equitability and investments into sociotechnical systems[17], [22]-[25].

In addition, some groups of authors [18], [19], [26] suggest using the term "energy poverty" in order to discuss problems related to insufficient access to energy services in developing countries and the term "fuel poverty" in order to characterise problems when households suffer from insufficient financial resources to pay for their basic needs in energy services.

The close link between energy poverty and a general lack of income or poverty has made researchers to investigate the "independence" of energy poverty, comparing the basic indicators of poverty with those indicators that pertain to energy poverty.

Addressing such research issues as whether fuel poverty differs from a low standard of living in general, as defined by the modified version of the national basic freedom indicator, or whether the risk factors of fuel poverty differ from the overall risk factors of household poverty, the authors of [27] have found out that the same factors are related to poverty in general and energy poverty. The link between problems in the quality of housing and material deprivation is as strong regarding poverty in general as it is regarding energy poverty. The results of numerical simulation show that the primary cause of a lack of fuel is a lack of resources rather than the housing problem. Energy poverty as measured by the self-evaluation indicator is not primarily related to the energy efficiency of the home but rather to the household's ability to afford an adequate standard of living. The authors conclude that the efforts in solving the fuel problem should focus on factors that cause poverty in general, for example, the ability to gain sufficient income (for example, a low level of education, a lower level of skills, the history of employment or unemployment and such limitations of workforce supply as the need to care for disabled adults or for children).

Contrary to the above, a number of studies point out and show empirically that energy poverty is a problem that is different from poverty in general since the former is sensitive to changes in energy prices and there is a large proportion of capital that is linked to the home and the energy efficiency of its equipment [8], [17], [25], [28]. In addition, the authors acknowledge that energy poverty is a multid-imensional phenomenon, and it is inadequate to judge it only based on low income, supporting the idea that energy poverty means not only a low level of income but inability to meet some kind of elementary basic needs. Still, the definition of these elementary needs is not an easy task [28] and attempts to define them provoking a discussion as to whether these needs mean the provision of a basic level of heating or a relative level of energy that is needed to ensure a healthy life in a certain society.

Summarising the energy poverty definitions of different countries (mainly EU member states) [9], [29], [30], [31], [32], it can be concluded that most studies link this phenomenon to an inability to adequately heat one's home or ensure adequate electric power supply, although in some cases, 
a wider concept, "energy services", is used. Still, it also has to be considered that disproportionate expenditure in relation to energy exposes the household to the risk of poverty in general. Energy poverty itself is related to low household income, high energy prices/expenditure and a low level of energy efficiency as well as to the way in which the energy is used. This means that energy poverty does not completely overlap with income poverty, although many households with a low level of income are energy poor as well. It has to be pointed out that a number of definitions encompass the concept of energy costs, yet the approaches to determining them are different. In addition, recent research emphasises the need to discuss and evaluate energy poverty not only from the point of view of energy consumption but also by assessing the sufficiency and usefulness of energy.

An equally important issue in relation to the definition of energy poverty concerns the population group that can be regarded as energy poor or vulnerable. In [33], it is pointed out that policymakers prefer energy poverty to be regarded as linked to groups with low income (the way it is reflected in the definitions used in Belgium, the United Kingdom, Austria, and France).

\subsection{The Causes of Energy Poverty and its Definition}

Although there is no unified definition or methodology, a number of projects and studies have attempted to evaluate the spread of energy poverty in the whole of Europe. As shown before - confirmed by several studies [14], [15], [34]-[36] -, the primary factors or causes that contribute to energy poverty are: a low level of income, high energy prices/costs and a low level of energy efficiency (especially in buildings). As can be seen in Fig. 1, the overlapping areas outline the spheres where there are indicators for measuring these aspects of energy poverty. For example, the type of the heating system as well as the fuel used influences energy consumption and energy efficiency; a high level of energy consumption results in larger energy bills, which has an adverse effect on households with a lower level of income. The energy poverty level of a household depends on the number and dimension of the factors that influence the household.

As can be seen, evaluation of energy poverty is a multi-dimensional problem and requires a combination of a number of indicators in order to obtain a detailed picture of the situation. This is also confirmed by[14], [21], [33]. Likewise, [37] concludes that the determination of energy poverty is a complicated task, although there are indicators (based on statistical data) that could be used for this purpose, such as the inability to maintain an adequate temperature at one's home, the percentage of population that have debts due to arrears on bills, or the number of homes where there are leaking roofs, cracks or other defects that influence the condition of the building.

As indicated in [38], the choice of the evaluation method also depends on whether the fact of energy poverty has to be determined at the European, national or regional level for the purposes of supervision and comparative evaluation, or there is a need for a more precise set of data so as to determine energy poor households or protected consumers for implementing a local policy. Equally important is the issue regarding the availability of the required data and resources to conduct additional empirical calculations as well as policy priorities regarding the determination of those social groups that need support. It has to be added, though, that there are discrepancies between the European-level and national statistical data. 


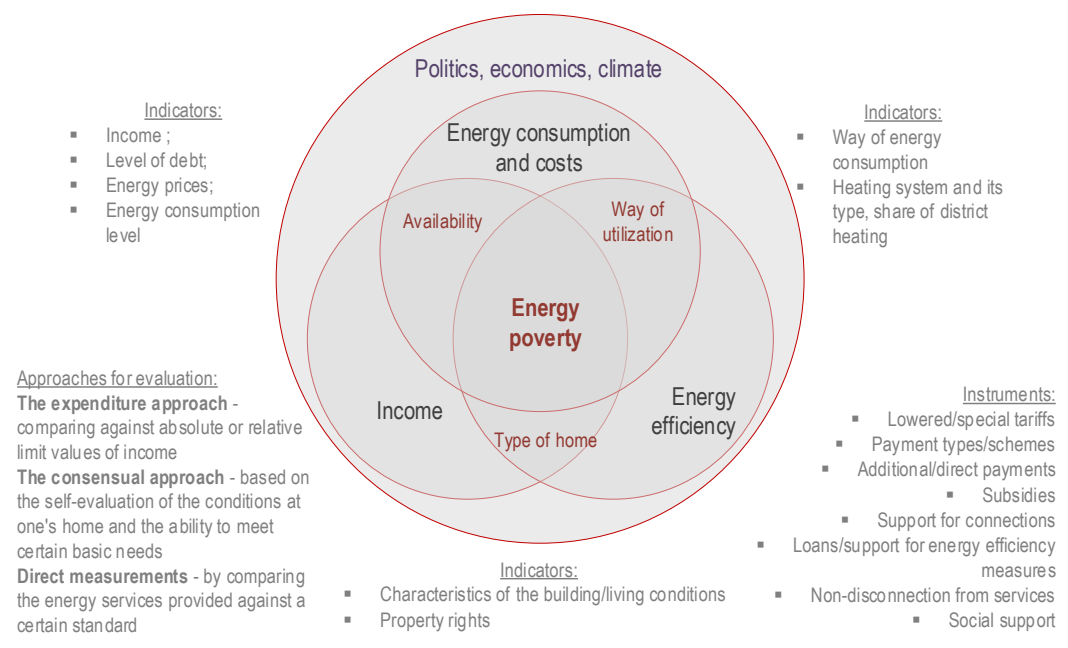

Fig. 1. The causes and indicators of energy poverty (interpretation by the authors, using the results of the Insight_E project [39]).

\subsection{Approaches and Measurement Methods for Evaluating Energy Poverty}

Three main approaches to the evaluation of energy poverty can be named [9], [38]:

- The expenditure approach: analysis/ comparison of how the energy expenditure of different households differs in relation to preset absolute and relative values;

- The consensual approach: collecting the subjective impressions of households regarding the level of energy services achieved at their homes, or collecting

\section{The Expenditure Approach}

This is one of the most widely used approaches. It is based on determining the relation between the energy expenditure of a household and its income. There are the following main methods/indicators to the expenditure approach [40], [41]:

- The Ten-Percent Rule (Boardman 1991, 2009);

- The Double Median or Mean Indicator (Boardman 1991, Hills 2012);

- Low Income, High Cost (LIHC) (Hills 2012);

- Minimal-Standard Indicator (MIS) the data of self-evaluation regarding the conditions at the homes, which can be used to make indirect judgements about the local degree of lack of energy;

- The direct measurement approach: checking the level of energy services (heating, lighting, cooling, etc.) at the home by conducting direct measurements, and comparing the values obtained with a certain standard.

(Moore 2012).

Some of the main reasons for the popularity of the expenditure approach are its objectiveness and its numerically definable nature, still it also receives a lot of criticism [38]:

- (Faulty) interpretation in other countries has suggested that the methodology is complicated and not easily transferable; the threshold value has to be individually determinable and justified (taking into account the specific conditions in each country) [42], [43]; 
- The formula-based fixed model for determining the required amount of heating may produce a misleading picture regarding the needs of the household [44]. In [45], it is pointed out that the narrowing of the scope of the causes of energy poverty to low income, insufficient conditions at dwellings and high energy prices fail to account for the significance of energy needs and sociodemographic conditions at the household scale. This particularly concerns people with special needs since, according to the research, they may have increased needs for energy services [11], [46].

\section{The Consensual Approach}

The consensual approach is based on the relative poverty approach and investigation of the self-evaluation of poverty [49]-[51]. It evaluates the inability of a household to "afford goods that the majority of society regards as basic needs in life". Usually, surveys contain questions about the following: the ability to adequately heat one's home; the ability to pay the utility bills; the presence of corresponding heating equipment; dampness in walls and/or floors; the availability of district heating; rotten window frames etc.

The consensual approach has a number of advantages [38]:

- In this method, it is less complicated to collect data as compared to the expenditure approach (especially for modelling needs); the method is suitable as a temporary measure for evaluating energy poverty in countries where there has been no comprehensive investigation regarding the condition of houses;

- At the European level, there are no standardised microdata regarding the energy costs of households or the condition of houses; thus, by using the coordinated indicators obtained in the EU-
Further, in [47] it has been found that some home owners prefer lower temperatures because of reasons other than financial limitations;

- It is difficult to apply this approach on the European scale and the specific contexts of different countries have to be taken into account. For example, in [48] it is proved that special attention has to be paid to the features of district heating systems that are widespread in countries of Central and Eastern Europe, like not allowing individual homes to regulate temperature or time settings.

SILC investigation, the energy poverty in the EU can be evaluated in quantitative terms;

- This method makes it possible to reach wider elements of energy poverty than those used in determining social exclusion and material insecurity; it is possible to evaluate a person's experience regarding energy poverty and the burden brought about by it; the respondents themselves make their evaluations as to what constitutes adequate heat and comfort levels.

Among the limitations, the subjectivity of indicators can be mentioned; the method is also criticized due to the exclusion error [21], [38], since a household may refuse to acknowledge itself as energy poor, although, if other indicators were used, the household would be in the risk group. In addition, "adequately warm or cool" is a subjective and culturally specific indicator [52], which means that a house that is usually regarded as well-lit and warm in one geographical context may fail to receive this assessment in a different one. Another cause for concern is the level of coincidence between self-evaluation indicators and 
actual expense indicators, for example, the authors of [53] found out that one-third of the households who stated that they could not keep their living space warm in winter had average or above-average income. This means that if the self-evaluation is erroneous, the person may look poor due to insufficient comfort rather than due to a lack of

\section{The Direct Measurement Approach}

The direct measurement approach evaluates whether a sufficient level of energy services (heating, lighting, cooling etc.) is ensured at a house, by conducting direct measurements and comparing the values obtained with a certain standard. Additional difficulties lie in the determination of appropriate standards of energy services, which are partly culture-specific.

According to [38], the direct measurement approach is not widely used in the European Union due to technical, practical and ethical issues. As explained in [55], even the temperature measurement approach, which theoretically seems simple, is fraught with problems due to several reasons, mainly because the data regarding temperatures at households are insufficient and are not plausible; also, irregular population density may distort the results if this approach is used. It is also important as to what threshold should be used to sig- resources [54].

Usually, this approach is applied (by using the data of the EU-SILC survey) to evaluate energy poverty at the European level, still in some countries, it is also used for investigating energy poverty at a national level.

nify an adequate heat level, as well as the above considerations regarding people with special needs. Moreover, in those countries where a large number of dwellings are serviced by district heating systems which do not allow individuals to control their heat consumption, for example, in Central and Eastern Europe, temperature is not a good indicator of a lack of energy since the indoor temperatures are "typically adequate, or in cases even too high" [48].

Still, the movement towards smart homes and the introduction of smart meters over the whole of the EU show a future potential of wider use of the direct measurement approach. Besides, the implementation of the Smart Energy City concept establishes favourable conditions for employment of smart technologies and unites the needs of citizens in a sustainable and secure way [56], [57].

\section{RESULTS AND DISCUSSION}

\subsection{An Analysis of Energy Poverty in the EU}

Definition of energy poverty and the criteria characterising it are complicated and multi-dimensional; an equally complicated task is to evaluate both the current level of energy poverty in European municipalities and its impact on the life of residents as well as to propose policy instruments to improve the situation.
Evaluating energy poverty according to the data of the Eurostat EU-SILC survey (see Table 1), it was found that in 2019, $7.0 \%$ of all the residents in the EU member states could not keep their dwellings adequately warm, whereas $13.1 \%$ reported problems regarding leaking roofs, dampness in walls, ceilings and foundations or rot 
in window frames, doors and floors; $6.1 \%$ of the residents had arrears on utility bills. In turn, the proportion of residents whose income was below the poverty line and who were financially unable to keep their dwellings adequately warm was 2.5 times higher $(17.8 \%)$ than the total proportion of all the residents with this problem (7.0 $\%)$ in the EU countries. A similar situation was observed among the residents (below the poverty line) who had arrears on utility bills: a 2.4 times larger proportion. In turn, one-fifth of the residents below the poverty line live at dwellings with dampness and rot problems. As a positive feature, it should be pointed out that since 2015, all the indicators have been gradually diminishing.

Table 1. Indicators Characterising Energy Poverty (2017-2019) [Eurostat: EU-SILC]

\begin{tabular}{|c|c|c|c|c|}
\hline Population share (\%) & EU & $\begin{array}{c}\text { EU } \\
\text { (below poverty line) }\end{array}$ & LV & $\begin{array}{c}\text { LV } \\
\text { (below poverty line) }\end{array}$ \\
\hline \multicolumn{4}{|c|}{ Inability to keep home adequately warm - EU-SILC survey [ilc_mdes01] } \\
\hline 2015 & 9.4 & 22.7 & 14.5 & 29.1 \\
2016 & 8.7 & 21.0 & 10.6 & 22.7 \\
2017 & 7.8 & 18.4 & 9.7 & 20.3 \\
2018 & 7.3 & 17.9 & 7.5 & 15.4 \\
2019 & 7.0 & 17.8 & 8.0 & 15.9 \\
\hline Living in a dwelling with a leaking roof, damp walls, floors or foundation, or rot in \\
\hline \multicolumn{5}{|c|}{ window frames or floor - EU-SILC survey [ilc_mdho01] } \\
\hline 2015 & 15.2 & 24.0 & 24.4 & 38.7 \\
2016 & 15.4 & 24.6 & 21.9 & 37.2 \\
2018 & 13.3 & 21.1 & 22.8 & 35.5 \\
2019 & 13.9 & 21.9 & 23.5 & 36.5 \\
\hline \multicolumn{5}{|c|}{ Arrears on utility bills - EU-SILC survey [ilc_mdes07] } \\
\hline 2015 & 13.1 & 21.0 & 16.7 & 30.0 \\
\hline 2016 & 9.1 & 18.5 & 13.2 & 11.9 \\
\hline
\end{tabular}

Upon comparing the indicators in Latvia with the EU average values, it can be concluded that residents in Latvia are more affected by problems regarding dampness or rot at dwellings as well as regarding the ability to pay utility arrears. On the other hand, their ability to keep their dwellings adequately warm is close to the EU average level; among the residents whose income is below the poverty line, the indicator is even better than the EU average.

According to statistics, these problems are most outspoken regarding elderly people, single people over 65 years of age, the unemployed, people who depend on social benefits, etc. The results may be of various kinds: insufficient heating affects hygiene, health (people have to choose whether to eat or live in warmth etc.), mobility limitations affect the employment situation, inability to heat the home or using inadequate heating systems results in an increased level of mortality, excessive debt, social and geographical isolation. Likewise, the author of [8] reports that the most vulnerable groups who are prone to poverty are elderly people, people with disabilities, young children, single parents and people with low income. The problem of a lack of fuel is more widespread in households with low income, who probably cannot afford to heat their dwellings to an adequate degree, especially if 
the energy prices are high and are increasing and when the dwelling is poorly insulated, thus causing a low fuel consumption efficiency level and, consequently, higher energy costs. As indicated in [8], this is due to a number of reasons: firstly, many low-income households rent their houses and, being tenants, they have no stimulus to invest into the energy efficiency of the houses; secondly, households with low income have more limited access to loans (for example, for the purpose of improving the heat insulation of the house); thirdly, households with low income do not invest into heat insulation improvements because of lacking information about energy efficiency possibilities and schemes and their use. Still, recent research regarding Ireland shows [58] that the relationships between the variable quantities of houses (including the type of dwelling, the age of the dwelling and housing quality problems) and the lack of fuel do not significantly differ from the relationship between the variable quantities of houses and basic deprivation. The results showed that energy poverty was mainly a problem of inadequate resources rather than housing quality, and it was found out that individuals in detached houses (who pay more for heat) were less poor than those who lived in semi-detached or terraced houses.
The authors conclude that the prime mover of a lack of fuel is the exceeding number of resources (i.e., income and savings) rather than heating or energy effectiveness costs.

Likewise, mobility is a heavy burden for the budgets of those households who live far from city centres and for whom transport is a precondition for being employed. According to [59], in the EU there are 10,000,000 people who have to walk for more than thirty minutes to reach public transport.

Notwithstanding the absence of a unified definition on the EU level, in some countries various indicators of energy poverty are in place and are used, as well as special rules have been developed regarding the protection of socially vulnerable consumers and support to them, for example, subsidized tariffs, free-of-charge tools (meters that operate on prepayment cards, supply guarantees), paying for the arrears on the utility bills, protection against disconnection of energy services, etc. Because of the large amount of attention devoted to this issue, a considerable academic and political knowledge base has been formed, along with an understanding about energy poverty as a wider inability to ensure a socially and materially necessary end-consumption energy level in a household [52].

\subsection{An Analysis of Energy Poverty in Latvia}

Up to now, the problems of energy poverty have not received detailed analysis in Latvia, although there are individual policy instruments for diminishing energy poverty. Within a study of the State Research Programme, an analysis of energy poverty along with an evaluation of the situation in Latvia has been made. Taking into account the above considerations and the available data, the analysis was performed using statistical data as well as the indicators recommended by the EU Energy Poverty Obser- vatory (EPOV).

Energy poverty in Latvia has been addressed in three characterising dimensions: low income, high costs of energy services and unsatisfactory housing conditions (primarily related to energy efficiency aspects).

It has to be pointed out that since 2015, Latvia has a completely liberalized electricity market and application of administratively regulated electricity prices in electricity sales to households has been dis- 
continued. In order to mitigate the potential adverse impact of price increases and the additional financial burden on the socially most vulnerable part of society, it was necessary to devise a tool for protecting these users. For this purpose, the concept of a "protected user" was introduced and a compensatory mechanism was formed. The protected user support mechanism defined in the Law on the Electricity Market only applies to support for electricity payments.
Therefore, similar support mechanisms should be defined for all energy services. Likewise, a unified system and a compensatory mechanism for diminishing energy poverty should be developed. When defining the group of protected users on the basis of sociodemographic features, an additional criterion should be set, i.e., the income limit, which may differ from category to category, considering their needs.

\section{The Income of Households and Residents}

Income is one of the main indicators when analysing energy poverty, as well as an important indicator when evaluating the risk of poverty or social exclusion. Since energy poverty is considered a variety of poverty, it is important to evaluate which groups of people are the most threatened ones in the context of low income.

In Latvia, there is a very high propor- tion of population (in $2019^{2}-27.3 \%$ or 518,000 people, Fig. 2) who are exposed to the risk of poverty or social exclusion, as well as the proportion of such residents (in $2019-22.9 \%$ or 434,000 people) whose disposable income is under the poverty risk line. The most widespread problem is low income as well as uneven distribution of income.

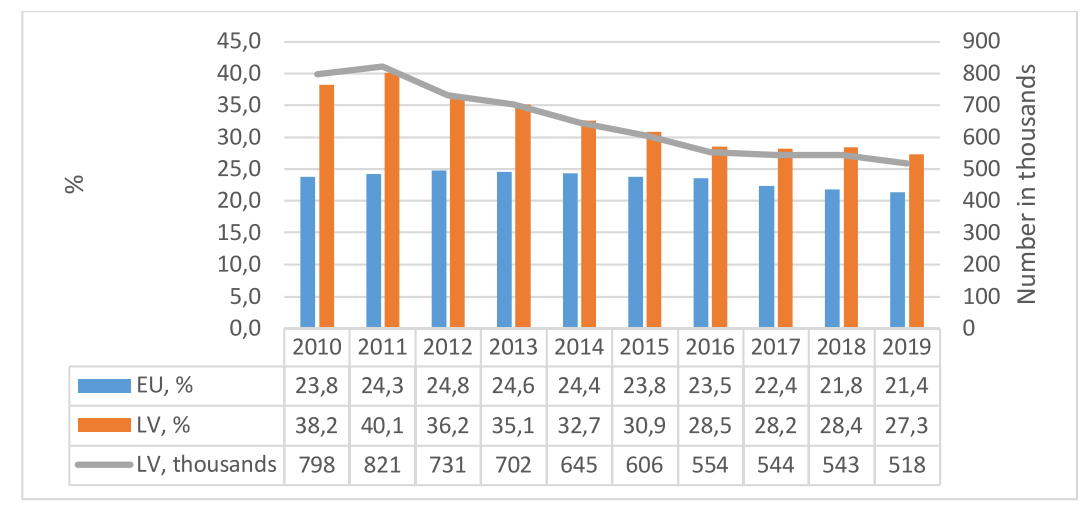

Fig. 2. People at risk of poverty or social exclusion, number in thousands and their proportion from the whole population (2010-2019); [Eurostat: ilc_peps01].

The groups with the most people exposed to the risk of poverty were the unemployed and retired people, followed by single-parent families with children and lonely persons below the age of 64 as well as multiple children families.
Disposable income is gradually increasing, yet this process is not even, nor equal in all the groups of quintiles of the income. There is a positive diminishing tendency regarding the change in the number and proportion of poor and deprived people.

\footnotetext{
${ }^{2}$ A difference in data registration: The Eurostat data correspond to the preceding year's data of the Central Statistical Bureau of Latvia
} 


\section{Households' Housing Expenditure}

According to the data of the Central Statistical Bureau of Latvia (see Fig. 3), the housing maintenance expenditure has risen by $9.2 \%$ since 2017 and was equal to an average of 150.74 EUR per month in 2019; households spent an average of $12.2 \%$ of their disposable income for these needs. Although there has been an increase in expenditure since 2011 (except for the years 2016 to 2017), its proportion from dispos- able income is gradually diminishing. The households who spent most for housing maintenance were couples with two children $(250 \mathrm{EUR} /$ month or $11.7 \%$ of the disposable income) and multiple children families $-226 \mathrm{EUR} / \mathrm{month}$ or $11.5 \%$ of the disposable income. Households consisting of one person spent the least amount of all but the proportion from disposable income was larger $(18.7 \%-22.2 \%)$.

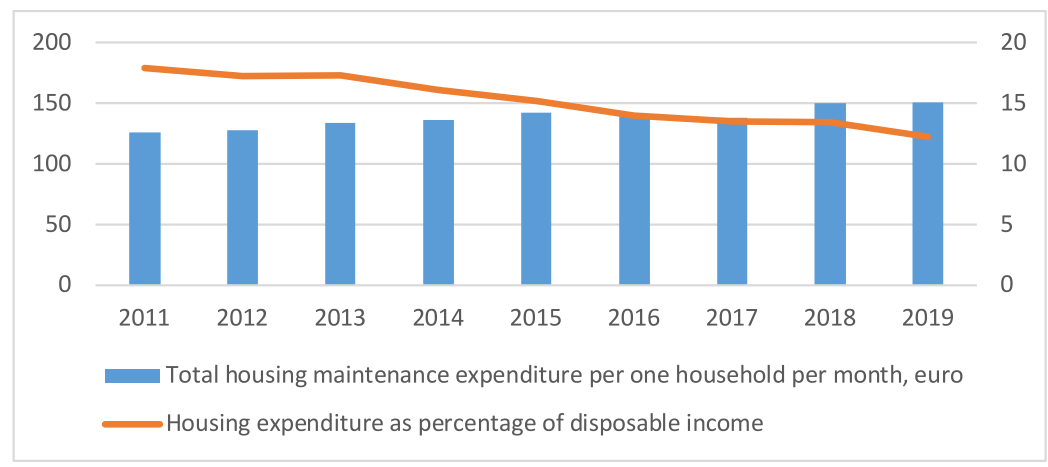

Fig. 3. Housing maintenance expenditure per household monthly and housing expenditure as percentage of disposable income [CSP: MTG050].

The experts interviewed in [60] point out that in the case of Latvia, difficulties may arise from the moment when housing expenditure amounts to as much as $20 \%$ of the household's total income, which is substantiated by the size of the remaining part of the income.

Upon evaluating the indicators of deprivation and housing expenditure, it was found out that on the whole, the deprivation

\section{The Ability to Pay for Utility Bills}

One of the indicators that characterise energy poverty is the amount of residents' arrears on utility bills. Looking at the Eurostat data regarding residents' arrears on utility bills, it is possible to identify the proportion of households who have had such arrears due to lacking finances. Since 2015 index and the economic stress indicators were falling, still the economic stress indicator was relatively high in the 1st and 2 nd groups of quintiles.

As indicated by [60], when determining the proportion of housing expenditure that does not cause financial difficulties for the household, it is important to take into account the average income of the residents of the country in question.

(see Table 1), the proportion of households who have arrears on utility bills due to lacking finances has diminished almost twofold (to $8.7 \%$ in 2019). The decrease has been the largest among households where there is a single adult with children (15.5\%) or an adult under 65 years of age (13.3\%). As 
can be seen from Fig. 4, among households whose income is below the poverty line, the arrears on the utility bills are highest in the cases of households consisting of two adults and two children $(25 \%)$ or an adult under 65 years of age $(20.3 \%)$.

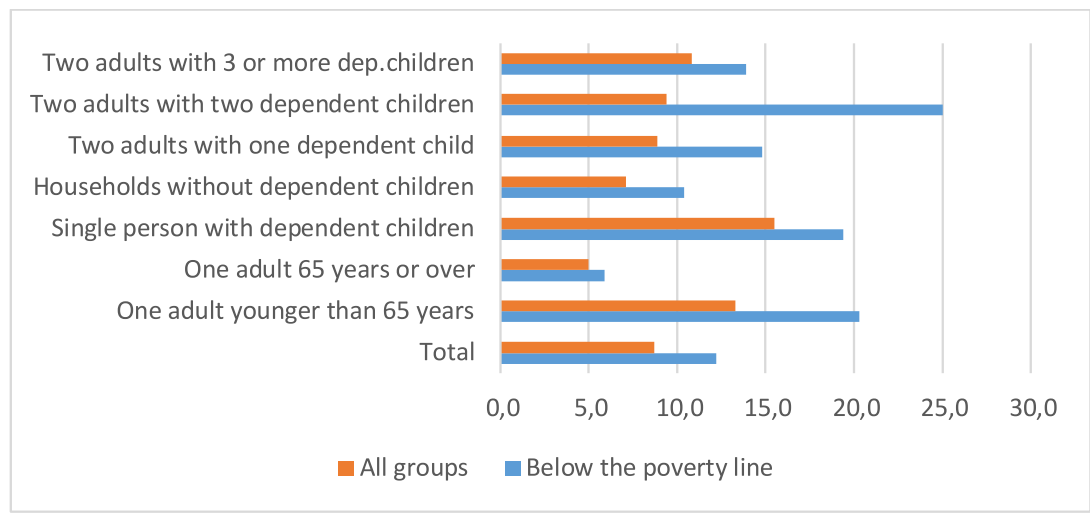

Fig. 4. Arrears on utility bills, \% (2018); [Eurostat: ilc_mdes07].

Although housing expenditure is a heavy burden for households consisting of one old-age person, still these households are mostly capable of paying for their utility bills, including those households whose income is below the poverty line.

According to the results of the survey of experts published in [60], looking from the point of view of inequality as regards affordability of housing, the experts pointed out that "one important problem consists in the housing costs for those population groups for whom they make up more than $20-30 \%$ of the total income of the household".

\section{The Financial Ability to Maintain the Home Adequately Warm}

The financial ability to maintain one's home warm is one of the criteria that characterise energy poverty. This indicator can be discussed both from the point of view of residents and from the point of view of dwellings. In addition, special attention has to be paid to analysing the housing resources and conditions.

The statistical data in Table 1 show that since 2015, the proportion of the residents who have difficulty in keeping their homes warm has decreased 1.8 times, falling to $8 \%$ in 2019 , which is close to the EU average $(7.0 \%)$. The tendency is similar among residents whose income is under the poverty line: an almost twofold drop since 2015, reaching $15.9 \%$ in 2019.

As shown in Fig. 5, the households most affected by this problem are those consisting of one adult above 65 years of age $(17.2 \%)$, one person with a child (14.1\%) and one person up to 64 years of age $(11.8 \%)$. The proportion of the single persons aged over 65 whose income is below the poverty line and who are financially unable to keep their homes adequately warm is almost twice as high $(17.2 \%)$ as the overall proportion of households $(9.7 \%)$ with this problem. 


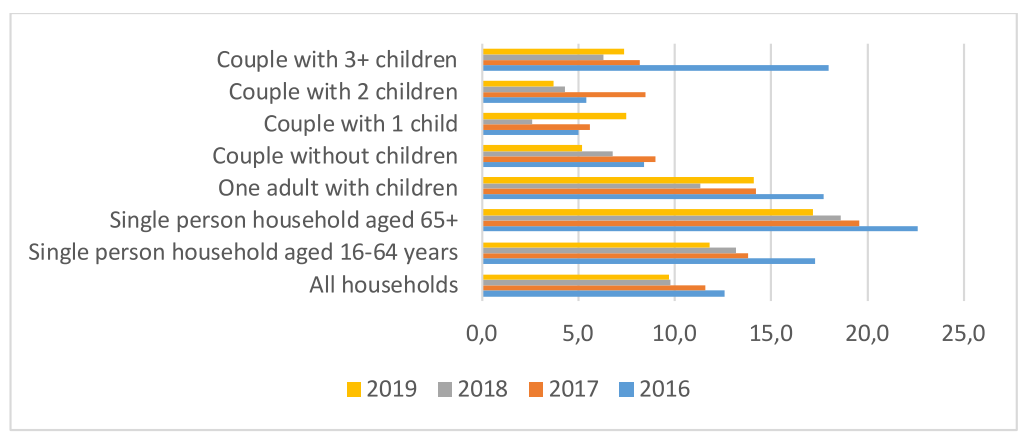

Fig. 5. The proportion of households that could not afford to meet certain expenses to keep their homes adequately warm due to the lack of finances (\%) [CSP: MNG010].

\section{Unsatisfactory Housing Conditions}

Problems related to leaking roofs, dampness or rot have a direct impact on energy efficiency and thus also influence the energy poverty situation. According to the data of the Central Statistical Bureau of Latvia, the proportion of residents whose households have unsatisfactory housing conditions is gradually diminishing. An analysis from the point of view of households (see Fig. 6) shows that in 2019, this problem was most frequent in households consisting of one adult with a child (27.4\%), as well as those consisting of one adult (19.7 and $18.6 \%$ ). This problem especially affects households with lower income.

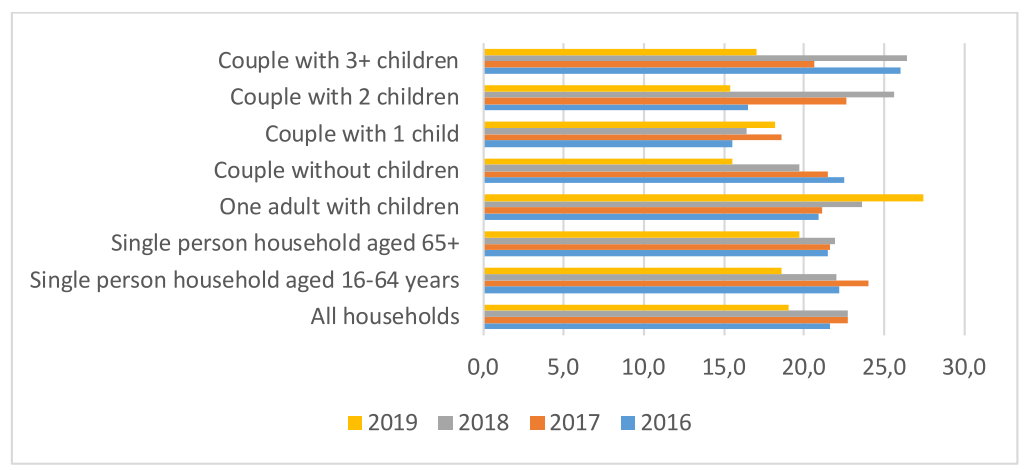

Fig. 6. The proportion of households that reported a leaking roof, damp walls/floors/foundation, or rot in window frames or floor, \% [CSP: MNG050].

In order to develop measures for improving the energy efficiency of dwellings and thus fighting energy poverty, it is important to evaluate the conditions of the housing resources and houses. As has been indicated in the 2018 annotation to the initial impact evaluation report for the draft law "Amendments to the Law on Assistance in Solving Housing Issues", which is based on data from the State Cadastre Information System, the current housing resources are considerably outdated, which increases the maintenance costs and, if the income of households does not increase, shifts the renewal prospects to a more distant future. $45 \%$ of multi-flat houses in Latvia were built until the year 1941 and $53 \%$ of the housing resources were built from 1961 to 
1992. From 1993 to 2014, the proportion of new multi-flat houses was only $2 \%$. The renewal of the multi-flat housing resources is very slow in Latvia; only $0.2 \%$ of the flats are built annually.

According to the data of the Central Statistical Bureau [MTG030; MTG020], the bulk of the households in Latvia $(62.8 \%)$ live in multi-flat houses with ten or more flats; $26.6 \%$ live in a detached house or in an individual farmstead. In 2019, the average area of one dwelling was $69.7 \mathrm{~m}^{2}$, with an average of 2.7 rooms, 1.2 rooms per household member.

\subsection{Policies and Good Practices for Diminishing Energy Poverty}

Defining energy poverty and its characterising criteria is a complicated and multidimensional task; an equally complicated task is to evaluate both the current level of energy poverty in European municipalities and its impact on people's lives, and to offer policy instruments for improving the situation.

According to [61], one of the departure points of the energy poverty exposedness approach is the understanding of the fact that those households that are, at a certain time moment, characterised as "poor from the point of view of energy services" may cease to be such if some conditions change; on the other hand, energy poverty may affect households that are not characterised as energy poor at the moment of their discussion. In order to help households to get out of energy poverty, different policy tools, measures and support mechanisms are developed and implemented. As indicated by the EESC, the main goal of such measures is to make the exposed consum- ers active solvers of their energy issues so that their consumption should diminish yet become more effective since that would improve the quality of their lives. In those cases when it is economically useful and technically feasible, decentralised energy production from renewable sources is supported. Information, instruction and education may help households to become aware of the problems encountered and to take correct action (to switch off equipment that is in standby mode; to choose energy-efficient equipment; to provide the necessary repairs, etc.).

As mentioned above, the problem of evaluating and diminishing energy poverty is complicated and multi-dimensional and it affects a number of different spheres. This has aroused wide discussions at the EU level, contributed to transfer of knowledge and development of various tools for addressing energy poverty. The main measures are shown in Table 2.

Table 2. Good Practice Instruments and Measures for Diminishing Energy Poverty

\begin{tabular}{|c|c|c|c|}
\hline $\begin{array}{l}\text { Financial } \\
\text { measures }\end{array}$ & $\begin{array}{l}\text { Consumer } \\
\text { protection }\end{array}$ & $\begin{array}{l}\text { Orientation } \\
\text { towards market }\end{array}$ & $\begin{array}{l}\text { Energy efficiency } \\
\text { of buildings }\end{array}$ \\
\hline $\begin{array}{l}\text { Earmarked } \\
\text { grants } \\
\text { General social } \\
\text { support } \\
\text { Subsidized } \\
\text { tariffs set }\end{array}$ & $\begin{array}{l}\text { Safety measures against } \\
\text { disconnection } \\
\text { Consumers' complaints } \\
\text { Awareness-raising campaigns and } \\
\text { dissemination of information } \\
\text { Direct supplier }\end{array}$ & $\begin{array}{l}\text { Objective and proved } \\
\text { price comparison tools } \\
\text { Codes of ethics } \\
\text { Modernized subsidies, } \\
\text { loans or tax relief }\end{array}$ & $\begin{array}{l}\text { Energy efficiency standards } \\
\text { Support from energy } \\
\text { companies for the energy } \\
\text { efficiency of low-income } \\
\text { residents } \\
\text { Subsidies for appliances }\end{array}$ \\
\hline
\end{tabular}


Notwithstanding the fact that it was only in 2020 that the concept of energy poverty was officially defined in Latvia and there was no methodology for its calculation. Individual measures have been defined and incorporated into normative acts that are directly or indirectly aimed also at diminishing energy poverty and protecting vulnerable users: support for electricity payments; support for setting up connections to the electricity grid; housing benefits; an energy efficiency programme; a guaranteed minimum income level; an energy efficiency obligation scheme; the Elektrum energy efficiency centre and the Dzīvo Siltāk (Live Warmer) activity.

It should be noted that recently (in 2021), changes regarding energy poverty have been implemented in the Energy Law in Latvia. According to it, a household is considered energy poor if:

1. It has been pronounced a low-income or poor household and receives material support for meeting the expenses related to the use of the housing;

2. It is renting housing or a public welfare flat owned by the municipality or rented by it, according to the law "On Help in Housing Issues" or the law "On Public Welfare Flats and Public Welfare Houses".

The official statistics of the Ministry of Welfare regarding social services and social welfare support show that the number of recipients of housing support gradually dropped from 113018 persons in 2015 (5.7\% of the total population) to 70954 persons in $2019(3.7 \%$ of the total population). Overall, the number of housing support recipients has dropped by $37 \%$ whereas the amount of financial means used for the housing support has diminished by $25 \%$ (from EUR 18390069 to EUR 13769 163), and the average size of housing support has increased by $19 \%$ (to EUR 194.06 in 2019).

In Latvia, housing support can be received by poor or low-income persons; the size, type and granting criteria of this support are determined by the municipalities. As a result, different municipalities use different criteria for determining an income level that corresponds to the status of a lowincome person; moreover, the procedure for estimating these levels is unclear. This problem is also highlighted by [60]: "the lack of unified criteria leads to a situation when persons in similar financial and social conditions are entitled to different levels of support both on the municipal level and on the national level". Such differences can even be present across the same region, for example, a person with an average monthly income of 350 EUR (in 2018) was entitled to support in Jekabpils, whereas a person living in Daugavpils or Rezekne (in the same Latgale region) with the same size of income could not receive this support since the 2018 average income limit for granting low-income status was 344 EUR in Daugavpils and 272 EUR in Rezekne. To address this issue, the further changes of laws and regulations are planned.

\subsection{Energy Communities and their Role in Diminishing Energy Poverty}

In order to reach the 2030 and 2050 energy and climate change mitigation goals, the central role has been appointed to the use of renewable energy sources. In addition, the market liberalization, departing from the traditional monopoly, has contrib- uted to the inclusion of more competitive and innovative participants into the energy market. Energy communities represent one type of such new participants. The Clean Energy Package defines citizen energy communities (Internal Electricity Market Direc- 
tive (EU) 2019/944) and renewable energy communities (Renewable Energy Directive (EU) 2018/2001).

As indicated in [6], the introduction of the initiative of energy communities contributes to the start of new energy services and activities, from renewable generation to investments into electromobility services. Energy communities may use a variety of legal forms. They can both engage in traditional activities and implement new entrepreneurship models. Usually, they are small resident-led initiatives in the form of a cooperative, connected with renewable energy generation activities. Yet, as pointed out in [6], more and more energy communities have taken on new functions of energy service providers: generation (collectively using or owning generation assets); supply (the sale and resale of electricity and gas; engagement in aggregation activities, etc.); consumption and sharing (individual and collective self-consumption; local sharing of energy within a community); distribution (ownership and/or management of community-run distribution networks); energy services (energy efficiency or energy savings; flexibility, energy storage and smart grid integration; energy monitoring and energy management; financial services); electromobility (car sharing, car-pooling and/or operation and management of charging stations, or provision of e-cards for members and cooperatives); and other activities (consultation services, information and awareness-raising campaigns, or fuel poverty measures). In this way, energy communities can help implement local sustainability projects, contributing to energy independence, diminishing carbon emisisons and energy poverty, as well as boosting local economies.

As shown in [6], energy communities diminish energy poverty, increasing the energy efficiency on the household level, reducing consumption and supply tariffs, for example, by supporting solidarity foundations and donating certain amounts from every consumed kilowatt-hour; by donating the overproduced energy amount, jointly meeting the energy service costs of the vulnerable users or diverting part of their profits to poverty mitigation.

\section{CONCLUSIONS}

Energy poverty is a new social priority. To define it, several characterising criteria need to be used: low income, large expenditure for energy services and housing quality in terms of energy efficiency. The definition of energy poverty is especially important for policy formulation; it impacts the scale and nature of the problem, as well as constant supervision and mitigation solutions.

Most good practices and measures implemented in individual EU member states concentrate on causes, for example, energy prices (for example, the "subsidized tariffs"), the quality of buildings (for example, improvement of energy efficiency in state-owned and private housing), low income (for example, financial support). Similarly, in some member states there have been corrective measures for mitigating the effects of energy poverty, for example, by forbidding disconnection of power supply services to more vulnerable families at critical moments.

To analyse and compare energy poverty in the European Union and Latvia, the following main indicators of the Eurostat EU-SILC survey have been used: inability to keep home adequately warm; living in a 
dwelling with a leaking roof, damp walls, floors or foundation, or rot in window frames or floor; arrears on utility bills. Since 2015, the proportion of the residents who have any of the mentioned difficulties has decreased both in the EU and Latvia. The tendency is similar among residents whose income is under the poverty line. However, in 2019 residents in Latvia were more affected by problems regarding dampness or rot at dwellings, this indicator $(19.3 \%, \mathrm{LV})$ was higher than the EU average (13.1\%) and almost equal to the EU level below the poverty line $(20.4 \%)$, households with lower income $(30.0 \%)$ were especially affected. On the other hand, the ability to keep homes adequately warm is close to the EU average level ( $7 \%$ in the EU, $8 \%$ in LV); among the residents whose income is below the poverty line, the indicator is even better than the EU average (17.8 \% in EU, $15.9 \%$ in LV). A similar situation was observed among the residents (below the poverty line), who had arrears on utility bills (14.6\% in the EU,

\section{$12.2 \%$ in LV).}

According to statistics, the most affected groups are elderly people, single people over 65 years of age, the unemployed, people who depend on social benefits, etc., resulting in an increasing level of inability to heat the home or using inadequate heating systems, health issues, unemployment, excessive debt and even mortality.

One of the main measures to diminish energy poverty in Latvia is housing support (for poor or low-income persons). In 2019 , the number of recipients of housing support was 70954 persons $(3.7 \%$ of the total population), whereas the amount of financial means used for the housing support was EUR 13769163 (an average of EUR 194.06 per person).

The initiative of energy communities fosters both technological and social innovation, as well as the introduction of socially more equitable energy prosumership models, thus diminishing energy poverty.

\section{ACKNOWLEDGEMENTS}

The research has been funded by the Ministry of Economics of the Republic of Latvia, project "Future-proof Development of the Latvian Power System in an integrated Europe (FutureProof)", project No. VPP-EM-INFRA-2018/1-0005.

\section{REFERENCES}

1. European Commission. (2015). Energy Union Package - A Framework Strategy for a Resilient Energy Union with a Forward-Looking Climate Change Policy. COM(2015) 80 Final, 1-21.

2. Kurevska, L., Sauhats, A., Junghans, G., \& Lavrinovics, V. (2020). Measuring the impact of demand response services on electricity prices in Latvian electricity market. In 2020 IEEE 61st Int. Sci. Conf. Power Electr. Eng. Riga Tech. Univ., (pp. 1-4), 5-6 November 2020, Riga, Latvia.
3. Petrichenko, L., Sauhats, A., Petrichenko, R., Borscevskis, O., \& Zima-Bockarjova, M. (2020). Billing system impact on the deployment of electric vehicles. In Int. Conf. Eur. Energy Mark. EEM, (pp. 2024), 16-18 September 2020, Stockholm, Sweden.

4. Sauhats, A., Zemite, L., Petrichenko, L., Moshkin, I., \& Jasevics, A. (2018). Estimating the Economic Impacts of Net Metering Schemes for Residential PV Systems with Profiling of Power Demand, 
Generation, and Market Prices. Energies, 11 (11), 3222.

5. Broka, Z., Kozadajevs, J., Sauhats, A., Finn, D. P., \& Turner, W. J. N. (2016). Modelling residential heat demand supplied by a local smart electric thermal storage system. In 201657 th Int. Sci. Conf. Power Electr. Eng. Riga Tech. Univ. RTUCON 2016 (pp. 259266), 13-14 October 2016, Riga Latvia.

6. Caramizaru, A., \& Uihlein, A. (2019). Energy Communities: An Overview of Energy and Social Innovation. EUR 30083 EN, Publications Office of the European Union, Luxembourg.

7. Koh, S. C. L., Marchand, R., Genovese, A., \& Brennan, A. (2012). Fuel Poverty: Perspectives from the Front Line. Research Report. Centre for Energy Environment and Sustainability.

8. O'Meara, G. (2016). A Review of the Literature on Fuel Poverty with a Focus on Ireland. Soc. Indic. Res., 128, (1), 285-303.

9. CAC. (2017). Tackling Energy Poverty. Manitoba Branch. Available at http://www. ic.gc.ca/app/oca/crd/dcmnt.do?Open=1\&id $=5042$ \&lang $=$ eng $\&$ wbdisable $=$ true

10. Hills, J. (2011). Fuel Poverty - The Problem and its Measurement," 2011.

11. Hills, J. (2012). Getting the Measure of Fuel Poverty. Final Report of the Fuel Poverty. London: Centre for Analysis of Social Exclusion. Available at https://sticerd.lse. ac.uk/dps/case/cr/CASEreport72.pdf

12. Day, R., Walker, G., \& Simcock, N. (2016). Conceptualising Energy Use and Energy Poverty Using a Capabilities Framework. Energy Policy, 93, 255-264.

13. Moore, R. (2012). Definitions of Fuel Poverty: Implications for Policy. Energy Policy, 49, 19-26.

14. Pye, S., Dobbins, A., Baffert, C., Ivana, J., De Miglio, R., \& Deane, P. (2015). Energy Poverty and Vulnerable Consumers in the Energy Sector across the EU. Policy Report 2. Available at https://ec.europa.eu/energy/ sites/ener/files/documents/INSIGHT_E_ Energy\%20Poverty\%20-\%20Main\% $\overline{20}$ Report_FINAL.pdf

15. Grevisse, F., \& Brynart, M. (2011). Energy
Poverty in Europe : Towards a More Global Understanding. Eur. Counc. an Energy Effic. Econ. 2011 Summer Study, 71, 537-549.

16. Bouzarovski, S., \& Petrova, S. (2015). The EU Energy Poverty and Vulnerability Agenda: An Emergent Domain of Transnational Action. Energy Policy Making in the EU, 129-144.

17. Bouzarovski, S. (2018). Energy Poverty. London: Palgrave Macmillan.

18. Simcock, N., Walker, G., \& Day, R. (2016). Fuel Poverty in the UK: Beyond Heating? People, Place and Policy, 25-41.

19. Thomson, H., Snell, C., \& Liddell, C. (2016). Fuel Poverty in the European Union: A Concept in Need of Definition? People Place and Policy Online, 10 (1), 5-24.

20. Deller, D. (2016). Energy Affordability in the EU: The Risks of Metric Driven Policies. Centre for Competition Policy, University of East Anglia. Available at http:// competitionpolicy.ac.uk/documents/ $8158338 / 11320618 / \mathrm{CCP}+\mathrm{WP}+16-9+$ complete.pdf/69d1f4ff-7301-493d-a2554de8d92b2280

21. Dubois, U. (2012). From Targeting to Implementation: The Role of Identification of Fuel Poor Households. Energy Policy, 49, 107-115.

22. Sovacool, B. K. (2012). The Political Economy of Energy Poverty: A Review of Key Challenges. Energy Sustain. Dev., 16, (3), 272-282.

23. Karekezi, S., McDade, S., Boardman, B., \& Kimani, J. (2012). Energy, Poverty, and Development. Global Energy Assessment: Toward a Sustainable Future, 151-190, Cambridge University Press.

24. Okushima, S. (2017). Gauging Energy Poverty: A Multidimensional Approach. Energy, 137, 1159-1166.

25. Okushima, S. (2016). Measuring Energy Poverty in Japan, 2004-2013. Energy Policy, 98, 557-564.

26. Castaño-Rosa, R., Solís-Guzmán, J., RubioBellido, C., \& Marrero, M. (2019). Towards a Multiple-Indicator Approach to Energy Poverty in the European Union: A Review. Energy Build., 193, 36-48. 
27. Watson, D., \& Maitre, B. (2015). Is Fuel Poverty in Ireland a Distinct Type of Deprivation? Econ. Soc. Rev. (Irel)., 46 (2), 267-291.

28. Walker, G., \& Day, R. (2012). Fuel Poverty as Injustice: Integrating Distribution, Recognition and Procedure in the Struggle for Affordable Warmth. Energy Policy, 49, 69-75.

29. EC DG VCWG. (2015). Working Paper on Energy Poverty. Available at https:// ec.europa.eu/energy/sites/ener/files/ documents/Working\%20Paper\%20on\%20 Energy\%20Poverty.pdf

30. Schumacher, K., Cludius, J., Forster, H., Greiner, B., Hunecke, K., Kenkmann, T., \& van Nuffel, L. (2015). How to End Energy Poverty? Scrutiny of Current EU and Member States Instruments. Policy Department A: Economic and Scientific Policy, European Parliament, Brussels.

31. González-Eguino, M. (2015). Energy Poverty: An Overview. Renew. Sustain. Energy Rev., 47, 377-385.

32. Strunck, C. (2017). Fighting Energy Poverty in Europe - Responses, Instruments, Successes. Available at http://library.fes.de/ pdf-files/wiso/13508.pdf

33. Rademaekers, K., Yearwood, J., Ferreira, A., Pye, S., Hamilton, I., Agnolucci, P. .... \& Anisimova, N. (2016). Selecting Indicators to Measure Energy Poverty. Trinomics. Rotterdam, the Netherlands. Available at https://ec.europa.eu/energy/sites/ener/files/ documents/Selecting $\% 20$ Indicators $\% 20$ to $\% 20$ Measure $\% 20$ Energy $\% 20$ Poverty.pdf

34. Thomson, H., \& Snell, C. (2013). Quantifying the Prevalence of Fuel Poverty across the European Union. Energy Policy, $52,563-572$.

35. Bouzarovski, S. (2011). Energy Poverty in the EU: A Review of the Evidence. University of Birmingham. Available at http://citeseerx. ist.psu.edu/viewdoc/download?doi=10.1.1.5 93.7020\&rep $=$ rep $1 \&$ type $=$ pdf

36. Energy Poverty Observatory (n.d.).European Fuel Poverty and Energy Efficiency. European Union. Available at https://www. energypoverty.eu/publication/diagnosis- causes-and-consequences-fuel-povertybelgium-france-italy-spain-and-united

37. EESK. (2010). Liberalizācijas un ekonomikas krīzes ietekme uz enerḡētisko nabadzību. Brisele.

38. Thomson, H., Bouzarovski, S., \& Snell, C. (2017). Rethinking the Measurement of Energy Poverty in Europe: A Critical Analysis of Indicators and Data. Indoor Built Environ., 26 (7), 879-901.

39. Pye, S., \& Dobbins, A. (2015). Energy Poverty and Vulnerable Consumers in the Energy Sector across the EU: Analysis of Policies and Measures. Policy ReportINSIGHT_E. Available at https://ec.europa. eu/energy/sites/ener/files/documents/ INSIGHT_E_Energy\%20Poverty\%20-\%20 Main\%20Report_FINAL.pdf

40. Heindl, P. (2013). Measuring Fuel Poverty: General Considerations and Application to German Household Data.. Ssrn, 13.

41. Schuessler, R. (2014). Energy Poverty Indicators: Conceptual Issues. Cent. Eur. Econ. Res. (ZEW), Discuss. Pap. Ser, 14 (14).

42. Healy, J. D., \& Clinch, J. P. (2002). Fuel Poverty in Europe: A Cross-Country Analysis Using a New Composite Measurement. Environ. Stud. Res. Ser, University College Dublin.

43. Liddell, C., Morris, C., McKenzie, S. J. P., \& Rae, G. (2012). Measuring and Monitoring Fuel Poverty in the UK: National and Regional Perspectives. Energy Policy, 49, 27-32.

44. Harrington, B. E., Heyman, B., MerleauPonty, N., Stockton, H., Ritchie, N., \& Heyman, A. (2005). Keeping Warm and Staying Well: Findings from the Qualitative Arm of the Warm Homes Project. Heal. Soc. Care Community, 13 (3), 259-267.

45. Bouzarovski, S., Petrova, S., \& Sarlamanov, R. (2012). Energy Poverty Policies in the EU: A Critical Perspective. Energy Policy, 49, 76-82.

46. Snell, C., Bevan, M., \& Thomson, H. (2015). Justice, Fuel Poverty and Disabled People in England. Energy Res. Soc. Sci., 10, 123-132. 
47. Critchley, R., Gilbertson, J., Grimsley, M., \& Green, G. (2007). Living in Cold Homes after Heating Improvements: Evidence from Warm-Front, England's Home Energy Efficiency Scheme. Appl. Energy, 84 (2), 147-158.

48. Tirado Herrero, S., \& Ürge-Vorsatz, D. (2012). Trapped in the Heat: A PostCommunist Type of Fuel Poverty. Energy Policy, 49, 60-68.

49. Townsend, P. (1979). Poverty in the United Kingdom. A Survey of Household Resources and Standards of Living. England: Penguin Books Ltd.

50. Mack, J., \& Lansley, S. (1985). Poor Britain. London: George Allen \& Unwin.

51. Gordon, D., Levitas, R., Pantazis, C., Patsios, D., Payne, S., Townsend, P. ... \& Williams, J. (2000). Poverty and Social Exclusion in Britain. York: Joseph Rowntree Foundation.

52. Bouzarovski, S. (2014). Energy Poverty in the European Union: Landscapes of Vulnerability. Wiley Interdiscip. Rev. Energy Environ., 3 (3), 276-289.

53. Palmer, G., Macinnes, T., \& Kenway, P. (2008). Cold and Poor: An Analysis of the Link between Fuel Poverty and Low Income. London: New Policy Institute.

54. McKay, S. (2005). Poverty or Preference: What do 'Consensual Deprivation Indicators' Really Mean?. Fisc. Stud., 25 (2), 201-223.

55. Phimister, E., Vera-Toscano, E., \& Roberts, D. (2014). The Dynamics of Energy Poverty: Evidence from Spain. Econ. Energy Environ. Policy, 4 (1), 153-166.
56. Mutule, A., \& Teremranova, J. (2018). Introduction of Energy Saving Principles: Technologies and Awareness, Latvian Experience. Latv. J. Phys. Tech. Sci., 55 (6), 52-62.

57. Mutule, A., Teremranova, J., \& Antoskovs, N. (2018). Smart City through a Flexible Approach to Smart Energy. Latv. J. Phys. Tech. Sci., 55 (1), 3-14.

58. Watson, D., \& Maitre, B. (2015). Is Fuel Poverty in Ireland a Distinct Type of Deprivation? The Economic and Social Review, 46 (2), 267-291.

59. Samek Lodovici, M., \& Torchio, N. (2015). Social Inclusion in EU Public Transport. European Parliament, Policy Department B: Structural and Cohesion Policies. Available athttps://www.europarl.europa.eu/RegData/ etudes/STUD/2015/540351/IPOL_ STU(2015)540351(SUM01)_EN.pdf

60. BISS. (2019). Ikgadējs nabadzības un sociālās atstumtības mazināšanas rīcībpolitikas izvērtējums (t.sk. izvērtējums par nevienlīdzību veselības aprūpē un nevienlīdzību mājoklı pieejamības jomā). Labklājības ministrija.

61. Middlemiss, L., \& Gillard, R. (2015). Fuel Poverty from the Bottom-up: Characterising Household Energy Vulnerability through the Lived Experience of the Fuel Poor. Energy Res. Soc. Sci., 6, 146-154. 